\title{
The Harberger-Laursen-Metzler Effect: Evidence from Pakistan
}

\section{Tayyaba Idrees* and Saira Tufail ${ }^{* *}$}

\begin{abstract}
According to the Harberger-Laursen-Metzler (HLM) effect, an exogenous temporary increase in the terms of trade leads to an improvement in the current account balance. This paper uses a recursive vector autoregression to investigate empirically the existence of the HLM effect in Pakistan, using a time series dataset for the period 1980-2009. Two important results emerge. First, real income deteriorates with an improvement in the terms of trade. Second, the current account balance also responds negatively to innovations in the terms of trade, which implies that the HLM effect does not exist in Pakistan.
\end{abstract}

Keywords: Terms of trade, current account, economic growth, recursive VAR, Pakistan.

JEL Classification: C3, F32, F41.

\section{Introduction}

Globalization, technological innovation, financial deregulation, and the growing level of cross-border integration have resulted in exceptionally high external imbalances, which are reflected in the frequent incidence of international current account crises. The terms of trade (TOT) are, arguably, a major determinant of the current account balance, and are extremely pertinent for developing countries because they are less able to influence world prices.

The relationship between TOT and current account balance can be explained in three different ways: First, according to the consumptiontilting effect, the current price of imports relative to their future price decreases owing to a favorable transitory TOT shock. Second, an exchange rate effect occurs if the price of tradables decreases relative to the price of nontradables. Third, the consumption-smoothing effect, commonly known as the Harberger-Laursen-Metzler (HLM) effect, induces current income to

\footnotetext{
* MPhil Student, Department of Economics, Fatima Jinnah Women University, Pakistan.

${ }^{* *}$ Lecturer in Economics, Department of Economics, Fatima Jinnah Women University, Pakistan.
} 
increase relative to future income (Harberger, 1950; Laursen \& Metzler, 1950). Broadly speaking, according to the HLM effect, the temporary improvement in TOT increases national savings, which subsequently improves the current account balance. On the other hand, a permanent improvement in TOT leads to a deterioration in the current account balance.

TOT has, by and large, remained unfavorable for Pakistan over the last three decades. The factors responsible for this disadvantageous position include the composition of exports, market concentration and inelastic demand for the import of capital goods, frequent devaluations of the currency, and external shocks. Being largely affected by TOT, Pakistan's current account balance has remained vulnerable to changes in domestic policy and the world economy. The deterioration in the current account balance has emanated mainly from the country's sharply widening trade deficit.

TOT is considered a key driver of fluctuations in real income and the current account in developing countries (Khan \& Knight, 1983). A deterioration in TOT results in lower national savings and increased dependence on foreign liabilities. This may, in turn, disrupt growth and lead to considerable economic instability. Given the worsening situation in the external sector in Pakistan on one hand, and the importance of TOT for achieving stable and sustainable economic growth on the other, it becomes vital to examine the nature of the relationship between the current account balance, economic growth, and TOT.

To this end, we investigate the presence of the HLM effect in Pakistan for the period 1980-2009. Though many researchers have assessed the effect of TOT on economic growth and current account balance separately, to our knowledge no effort has been made so far to capture this effect for Pakistan. The framework we adopt is based on Otto's (2003) study, which employs a three-variable vector autoregression (VAR), using TOT, current account balance, and economic growth, to capture the HLM effect. An impulse response function indicates the nonexistence of the HLM effect in Pakistan. Furthermore, the forecast error variance decomposition shows that the macroeconomic variables used barely explain the movement in the current account.

The rest of the study is organized as follows: Section 2 presents a theoretical and empirical appraisal of the existing literature on the HLM effect. Section 3 describes our methodology and data. Section 4 presents the estimation and results of the impulse response function and forecast 
error variance decomposition. Section 5 concludes the study with some policy recommendations.

\section{Literature Review}

\subsection{Theoretical Viewpoint}

The literature on the HLM effect can be divided into three strands: (i) the consumption-smoothing effect, (ii) the consumption-tilting effect, and (iii) the exchange rate effect. The consumption-smoothing effect was first explained by Harberger, (1950) and Laursen \& Metzler, (1950), and says that an improvement in TOT results in an improvement in the trade balance if changes in investment and government expenditure remain constant. ${ }^{1}$ Sachs (1981) was the first to challenge their work, adopting a dynamic equilibrium model ${ }^{2}$ based on a lifecycle savings model, to conclude that a transitory change in TOT brings about a positive change in the current account, whereas a permanent change in TOT has an ambiguous impact on the current account. Obstfeld (1982) extended this idea to maximize indirect utility: ${ }^{3}$ Following the savings channel, he observed a negative change in the current account due to unanticipated positive changes in TOT.

Svensson and Razin (1983) incorporate the substitution effect to test the theoretical basis of the HLM effect. They find a positive relationship between the current account and unanticipated transitory changes in TOT. Extending their work, Edwards (1989) analyzes the effects of temporary and permanent external TOT shocks on the current account by adopting the elasticity approach. ${ }^{4}$ The results support the existence of the HLM effect.

Persson and Svensson (1985) adopt an overlapping generations model for two goods and analyze the current account dynamics of a small open economy, while considering the savings channel through the income effect. The intertemporal approach states that consumption and savings are dynamic at different points in time ${ }^{5}$. Sen and Turnovsky (1989) analyze the effects of deterioration in TOT on a small open economy, adopting an

\footnotetext{
${ }^{1}$ A single-good static, Keynesian open economy model, assuming that the marginal propensity to consume is less than unity.

${ }^{2}$ Employing a single-good model and a small open economy.

${ }^{3}$ By using a two-good utility-type function.

${ }^{4}$ Elasticity approach: using a three-good (imports, exports, and nontradables) model.

5 A two-good model (imports, exports)-more specifically, optimization behavior under the intertemporal budget constraint.
} 
intertemporal optimization model. They examine the savings and investment channel while incorporating labor-leisure choice, and find results contrary to those predicted by the HLM effect. The intertemporal approach (consumption-tilting effect) entails microeconomics-based analysis whereas the absorption approach derives macroeconomic analyses (Obstfeld \& Rogoff, 1994).

Servén (1995) analyzes the consequences of permanent and transitory changes in TOT, and concludes that the conventional HLM effect does not exist. He argues that excluding capital-intensive good imports has given rise to the misleading view that the HLM effect exists. He explains this uncertainty in the light of three major factors: (i) the import content of consumption and investment, (ii) the duration of a shock, and (iii) the extent of intertemporal substitution in consumption and investment. Additionally, under the intertemporal substitution effect, the exchange rate is potentially an important variable through which TOT shocks are transmitted to the current account. Cashin and McDermott (2002) examine the downward trend in real commodity prices while considering their behavior. They find a negative and significant relationship between temporary changes in TOT and current account deficits for developing countries.

\subsection{Empirical Viewpoint}

Our theoretical analysis has been verified empirically by comprehensive cross-country studies based on the determinants of the current account. TOT shocks and their impact on the current account have been evaluated empirically using a variety of econometric techniques, including cross-country panel regression models, VAR models, and twostage least squares (2SLS) models.

\subsubsection{Studies Supporting HLM Effect}

TOT variations are, typically, key drivers of fluctuations in the real income of developing countries, which depend on trade in primary commodities. Khan and Knight (1983) use pooled time-series crosssectional data for 32 nonoil-producing developing countries for the period 1973-80 to analyze which factors affect their current account balances. Using simple ordinary least squares (OLS), they deduce that the empirical evidence supports the existence of the HLM effect in these countries. Using pooled time-series data for 14 Asian developing countries for the period 1961-83, and incorporating 2SLS with country dummies, Fry (1986) 
estimates the national savings, domestic investment, and economic growth rate functions. The results correspond to the HLM effect.

Ostry and Reinhart (1992) provide a rationale for temporary TOT shocks, using a disaggregated commodity structure in which an agent consumes both tradables and nontradables. Their analysis is based on three different channels for four countries in Africa and Latin America each and five countries in Asia for the period 1968-87: (i) consumer behavior and regional diversities, (ii) intertemporal substitution elasticities, and (iii) estimates of intratemporal elasticity. Razin (1993) illustrates the logic and empirical validity of the dynamic optimizing approach to the current account, showing how various shocks affect saving and investment performance. The study's analysis is based on data from seven developed and 21 developing countries for the period 1960-89.

To study the response of the current account to TOT shocks and its degree of persistence, Otto (2003) has conducted an empirical study of small open economies, using structural VAR models and an impulse response function. He includes annual data on 15 small OECD economies for the period 1960-96 and on 40 developing countries for the period 196097. The results are compared with those of Mendoza (1995). Except for a few countries, the HLM effect is observed in the rest of the sample and the results are consistent with the theory. Finally, Misztal (2010) tests the distribution chain between variables, using a VAR model for Poland for the period 1995 (first quarter) to 2009 (third quarter). The results reveal the existence of the HLM effect in Poland.

\subsubsection{Studies not Supporting HLM Effect}

Khan, Hasan, and Malik (1992) analyze several determinants of savings in Pakistan besides income and interest rates. These determinants include the dependency ratio, foreign capital inflows, foreign aid ${ }^{6}$ changes in TOT, the openness of the economy, and other financial variables. For estimation purposes, the authors use time-series data for the period $1959 / 1960$ to $1987 / 1988$, employing OLS. Although the study follows the theoretical concept presented by Obstfeld (1982), its results lead the authors to infer that the HLM effect does not exist in Pakistan.

In the context of the medium-term determinants of the current account in industrial and developing countries, Chinn and Prasad (2003) use a dataset for 18 industrial and 71 developing countries (which, for most

\footnotetext{
${ }^{6}$ Foreign trade includes project and nonproject aid.
} 
countries in the sample, covers the period 1971-95). Applying cross-section and panel regression techniques, the authors' results show that, in developing countries, higher TOT instability is associated with larger current account surpluses-which is contrary to the HLM effect.

Controlling for various standard determinants of private savings, Agénor and Aizenman (2004) empirically test for the existence of the HLM effect in nonoil-producing sub-Saharan African countries for the period 1980-96. The findings of this study do not support the existence of the HLM effect. Hassan (2006) uses a co-integration and error correction model to analyze the behavior of Bangladesh's current account deficit for the period 1976-2002. The results reveal that the country's TOT appears to be the only variable with a statistically positive impact on the current account deficit - a result that contradicts the validity of the HLM effect.

Each of these alternative perspectives-the elasticity, absorption, intertemporal, and intratemporal approaches-has a different way of explaining current account movements in different groups of economies over different time horizons. However, the evidence provided by the studies outlined above is still inconclusive on the issue of current account determinants in South Asia. Our study analyzes the HLM effect for a group of countries, omitted in most studies.

\section{Methodology and Data}

\subsection{Methodology}

In order to ascertain the existence of the HLM effect, we use a VAR model. Many researchers (Bouakez \& Kano, 2008; Cashin \& McDermott, 2002; Misztal, 2010; Onder \& Anil, 2006; Sobrino, 2008) have investigated the existence of the HLM effect using different forms of VAR. The choice of estimation technique rests largely on the objectives of the study. In this case, an analysis of distribution chain and forecasting is involved, which can be appropriately carried out using a VAR. We develop a three-variable recursive VAR system, which includes (i) TOT ( tot $\left._{\mathrm{t}}\right)$, (ii) real output $\left(\mathrm{y}_{\mathrm{t}}\right)$, and (iii) the current account $\left(\mathrm{ca}_{\mathrm{t}}\right)$. The model is given as follows:

$$
X_{t}=A(L) X_{t-1}+U_{t}
$$

where $X_{t}$ is the $3 \times 1$ vector of endogenous variables, i.e.: $X_{t}^{\prime} \equiv\left[\operatorname{tot}_{t}, y_{t}, c a_{t}\right]$ 
$A(L)$ is a $3 \times 3$ matrix of lag polynomials and $U_{t}$ is the $3 \times 1$ vectorreduced form innovation, i.e., $U_{t} \equiv\left[u_{t}^{t o t}, u_{t}^{y}, u_{t}^{c a}\right]$. These residuals are independently and identically distributed with a variance-covariance matrix, where

$$
E\left(U_{t}\right)=0 ; E\left(U_{t} U_{t}^{\prime}\right)=\sum u_{t}
$$

Amisano and Giannini (1997) suggest an AB model for the relationship between reduced-form and form structural shocks:

$$
A U_{t}=B V_{t}
$$

$V_{t}$ represents structural shocks while $A$ and $B$ are $3 \times 3$ matrices that reflect the instantaneous relationship between variables and the linear relationship between shocks and reduced-form innovation, respectively. The remaining steps involved in deriving the final form of the model are presented in Appendix A.

The fundamental problem with recursive models is that one cannot directly estimate and derive the values of $\mathrm{A}$ and $\mathrm{B}$ in order to extract meaningful implications from the model given above. The basic purpose of identification is to transform the correlated innovation of a reduced-form model into uncorrelated and theoretically meaningful structural shocks. Generally, Sim's (1980) restrictions are imposed on the contemporaneous properties of the system, usually known as short-run restrictions. Various short-run identification schemes have been developed in the literature, which can be broadly classified into two categories: (i) triangular restrictions and (ii) nontriangular restrictions. The triangular or recursive approach to identification restricts $\mathrm{B}$ in equation (2) to an $n$ dimensional identity matrix and A to a lower triangular matrix with a unit diagonal. The recursive approach involves a causal ordering of variables in a given model. In the case of an $m$ variables model, $m$ ! total orderings are possible. A nontriangular scheme of identification, however, allows us to impose restrictions that are econometrically and theoretically feasible, that is, restricted matrices are fully ranked. The identification problem can be illustrated by reproducing the AB model in equation (2) as:

$$
A U_{t}=B V_{t}
$$




$$
\left[\begin{array}{ccc}
\alpha_{11} & 0 & 0 \\
\alpha_{21} & \alpha_{22} & 0 \\
\alpha_{31} & \alpha_{31} & \alpha_{33}
\end{array}\right]\left[\begin{array}{c}
\varepsilon_{t}^{t o t} \\
\varepsilon_{t}^{y} \\
\varepsilon_{t}^{c a}
\end{array}\right]=\left[\begin{array}{lll}
1 & 0 & 0 \\
0 & 1 & 0 \\
0 & 0 & 1
\end{array}\right]\left[\begin{array}{c}
\mu_{t}^{t o t} \\
\mu_{t}^{y} \\
\mu_{t}^{c a}
\end{array}\right]
$$

The ordering of variable in our system has a strong theoretical and factual rationale. First, although fluctuations in TOT can be attributed both to internal and external factors, the composition and volume of trade render Pakistan's TOT relatively more vulnerable to external shocks. This is why the variable is considered the most exogenous in the system. Second, the coefficient of real GDP, which is partially endogenous, is affected by TOT in the system. The impact of TOT on GDP is, ceteris paribus, ambiguous. The current account is the only endogenous variable that is affected by the other variables (TOT, real GDP) in the system. The relationship between TOT and current account has been discussed above.

However, there is both a negative and positive relationship between output and the current account balance. There are two ways in which higher output affects the current account negatively. First, an increase in real output increases import demand and, therefore, results in a current account deficit. Second, if there is an increase in real GDP, domestic investment is stimulated, generating capital inflows into the country. As a result, real GDP causes the current account balance to worsen. The country exports goods and services to other countries if it experiences an increase in domestic output that is larger than its domestic absorption. In this way, real output is positively associated with the current account balance.

\subsection{Data}

This study covers a 30-year period from 1980 to 2009. All the data has been retrieved from the World Data Bank, World Development Indicators, and Global Development Finance. The data used comprises three variables: TOT, real output, and current account balance. We use the net barter TOT index (base year $2000=100$ ). Real output is measured by real GDP (base year $2000=100$ ) and the current account balance is taken as a percentage of GDP. TOT and real GDP are used in log form. Table 1 presents the summary statistics of the main variables. 
Table 1: Summary statistics

\begin{tabular}{llll}
\hline Statistic & \multicolumn{1}{c}{ tot $_{\mathbf{t}}$} & \multicolumn{1}{c}{$\mathbf{y}_{\mathbf{t}}$} & \multicolumn{1}{c}{$\mathbf{c a}_{\mathbf{t}}$} \\
\hline Observations & 30 & 30 & 30 \\
Mean & 4.64 & 10.98 & -2.75 \\
Median & 4.71 & 11.03 & -3.31 \\
Standard deviation & 0.24 & 0.41 & 3.06 \\
\hline
\end{tabular}

Source: Authors' calculations.

\section{Estimations and Discussion of Results}

Using a VAR model, this section provides empirical evidence on the existence of the HLM effect in Pakistan. The VAR model traces the response of a system to an innovation in one variable. VAR models have been shown to be good at capturing co-movements in time-series estimation (Stock \& Watson, 2001). Before applying VAR, however, we conduct a number of time-series diagnostic tests. The steps involved in estimating the model are described below.

\subsection{Time-Series Diagnostic Tests and Lag Order Selection}

Determining the stationarity of variables is a prerequisite to applying the VAR model, for which purpose we use the augmented Dickey-Fuller (ADF) test (see Bhargava, 1984). The results of the ADF test for both levels and first differences are summarized in Table 2. The null hypothesis of the unit root is statistically accepted at a 1 percent level of significance. This shows that the data is not stationary in levels. However, the hypothesis of the unit root test is rejected for all the variables in first differences, showing that the data is stationary in first differences [I (1)].

Table 2: Results of ADF test

\begin{tabular}{lcclcc}
\hline & \multicolumn{2}{c}{ Levels } & \multicolumn{2}{c}{ First differences } & \\
\cline { 2 - 5 } Variable & t-statistic & p-value & t-statistic & p-value & Conclusion \\
\hline tot $_{t}$ & -1.42 & 0.833 & $-5.63^{* * *}$ & 0.0005 & $\mathrm{I}(1)$ \\
$\mathrm{y}_{\mathrm{t}}$ & -2.11 & 0.520 & $-3.7^{* *}$ & 0.0388 & $\mathrm{I}(1)$ \\
$\mathrm{ca}_{\mathrm{t}}$ & -2.39 & 0.376 & $-5.07^{* * *}$ & 0.0027 & $\mathrm{I}(1)$ \\
\hline
\end{tabular}

Note: ${ }^{* * *},{ }^{* *}$, and ${ }^{*}$ show $1 \%, 5 \%$, and $10 \%$ levels of significance, respectively. Source: Authors' calculations. 
In order to ensure stability when dealing with the VAR model, we apply three further tests. The first, Schwarz's Bayesian information criterion, is applied to determine the correct VAR order or lag length. According to the results in Table 3, it is optimal to include one lag in the model for further VAR estimations. The second test, the Chow test, is used to check the structural stability of the data. Structural breaks are checked for in 1992, for the floods that occurred in southern Pakistan, and for 2005, for the devastating earthquake. The results of the Chow test are reported in Table 4 and give strong evidence of structural breaks in the data. Accordingly, we include dummies for these years in the model. The third test is used to derive a correlation matrix to assess the strength of correlation between the selected samples. The results presented in Table 5 do not indicate evidence of strong correlation among the variables.

Table 3: VAR lag order selection criteria

\begin{tabular}{lc}
\hline Lag & Schwarz information criterion \\
\hline 0 & 5.195 \\
1 & $-1.828^{*}$ \\
2 & -1.597 \\
\hline
\end{tabular}

Note: * indicates lag order selected by the criterion.

Source: Authors' calculations.

Table 4: Chow break-point test

\begin{tabular}{lcccc}
\hline Variable & F-statistic & Prob. $\mathbf{F}(\mathbf{3}, \mathbf{2 4})$ & $\begin{array}{c}\text { Log likelihood } \\
\text { ratio }\end{array}$ & $\begin{array}{c}\text { Prob. chi-square } \\
\text { (3) }\end{array}$ \\
\hline $\begin{array}{l}\text { Chow break-point test: } 1992 \\
\text { tot }\end{array}$ & & & \\
10.3714 & 0.000145 & 24.94075 & 0.000016 \\
$\begin{array}{l}\text { Chow break-point test: } 2005 \\
\text { tot }\end{array}$ & 14.06406 & 0.000017 & 30.43525 & 0.000001 \\
\hline
\end{tabular}

Source: Authors' calculations.

Table 5: Correlation matrices

\begin{tabular}{lccc}
\hline & tot $_{\mathbf{t}}$ & $\mathbf{y}_{\mathbf{t}}$ & $\mathbf{c a}_{\mathbf{t}}$ \\
\hline tot $_{\mathrm{t}}$ & 1.000 & -0.158 & 0.208 \\
$\mathrm{y}_{\mathrm{t}}$ & -0.158 & 1.000 & -0.305 \\
$\mathrm{ca}_{\mathrm{t}}$ & 0.208 & -0.305 & 1.000 \\
\hline
\end{tabular}

Source: Authors' calculations. 


\subsection{Impulse Response Function}

The relationship between TOT, current account balance, and real output is evaluated using an impulse response function. These impulses are derived using a recursive VAR model, in which Cholesky one-standard deviation shocks are applied and the response estimated over a period of ten years, 2009-19, following the initial occurrence of the shocks. The impulses are presented in Figure 1. Appendix B reports the results of the VAR.

\subsubsection{Response of TOT to TOT}

Panel 1 of Figure 1 shows the response of TOT due to one standard deviation of unanticipated positive shock to itself-a gradual decline in Pakistan's TOT. The dashed line becomes parallel to equilibrium after the seventh year. This shows that the positive shock to TOT is transmitted completely to TOT itself. There is a continuous decline in TOT; asymptotically, it will converge to equilibrium in the long run, which verifies the stability of the model.

\subsubsection{Response of real GDP to TOT}

Panel 2 of Figure 1 shows the dynamic response of economic growth due to one standard deviation of positive unanticipated shock to TOT. Initially, real output starts rising in response to the exogenous shock to TOT. It remains negative till the second year, and then converges with equilibrium. Economic growth gradually starts declining and further deviates from equilibrium in subsequent years, showing a negative relationship between TOT and economic growth. This reveals that Pakistan's real output has responded negligibly to a transitory TOT shock.

Given a boom in commodity prices, TOT improves due to an appreciation in the real exchange rate. Consequently, real output falls due to this mechanism-also known as "Dutch Disease" (Hernández, 2011). Murphy (1983) demonstrates that several countries experienced TOT improvements that led to current account deterioration. According to her study, the responsibility lies with leaders who transfer the gain from improved TOT either to inefficient local projects or to finance their interests. Even if the government is aware of the fact that the shock is temporary, they squander the gain by investing frequently in low-return activities. The improvement in TOT has a negative relationship with real output because the gains from this improvement are either consumed or invested in low-return projects. Gelb (1988) and Tornell and Lane (1994) 
attribute this to a "voracity effect", which counteracts the consumptionsmoothing effect, inducing a decline in the current account in response to a positive transitory shock to TOT.

\subsubsection{Response of Current Account to TOT}

Panel 3 of Figure 1 shows the impact of a one-standard deviation shock to TOT on the current account balance. We observe a moderate impact on the current account due to an unanticipated shock to TOT. Pakistan's current account balance initially appears positive, but drops gradually in the second year and reaches its lowest level in the third year. From this point onward, it starts rising and becomes parallel to equilibrium in the eighth year. This response is in line with Otto's (2003) study, where the current account's response to positive TOT shocks is not significant for Pakistan. Our results are consistent with Khan et al. (1992), who examine the determinants of savings in Pakistan, using OLS. Their results suggest that the savings rate in Pakistan increases with a deterioration in TOT. These results also support those of Chinn and Prasad (2003).

The results are, however, in contrast to the HLM effect, which can be explained by the intertemporal substitution effect. This effect is attributed to current account deterioration owing to TOT improvement. The consumption-based interest rate decreases, which further reduces the cost of current consumption in terms of future consumption. This implies a decline in savings, which contributes to the current account's deterioration (Goodger, 2001). Pearce (1955) has emphasized that any substitution effect between savings and consumption will depend on changes in the real

interest rate. Razin (1993) also examines the negative relationship between TOT improvements and the current account. 
Figure 1: Response to Cholesky One S.D Innovations $\pm 2 S . E$ for Pakistan
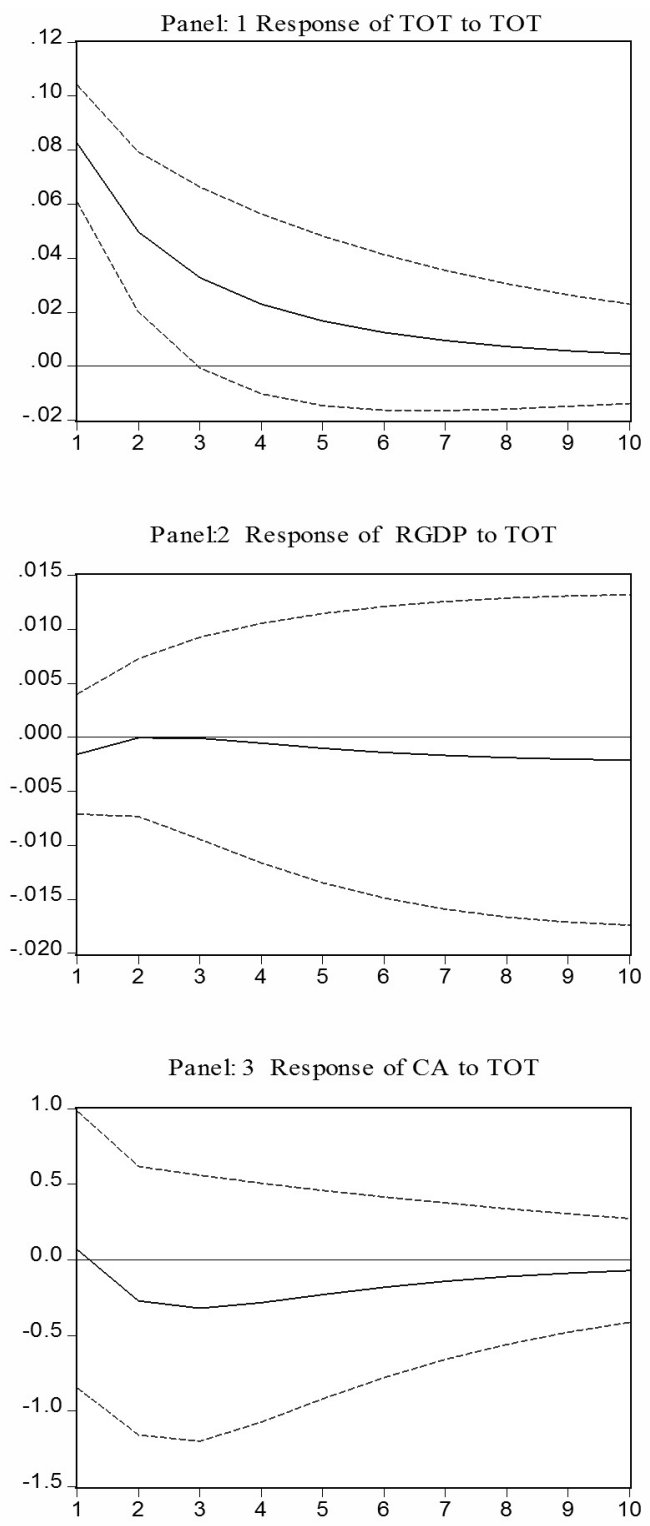

\subsection{Variance Decomposition}

A variance decomposition shows the contribution of each shock to the variance of n-period-ahead forecast error of the variable. In other words, through variance decomposition, we can find out to what extent the variable is affected by fluctuations in different shocks over different horizons (Onder \& Anil, 2006). 
Table 6 presents the variance decomposition for three endogenous variables, showing that most of the forecast error variance in TOT is explained by the variable itself. Current account innovation plays a relatively significant role, contributing around 22.0 percent to the forecasted error of TOT. Economic growth makes a minute contribution to the TOT standard error, even over longer time horizons $(0.63$ percent of the forecast error variance of TOT).

Table 6: Forecast error variance decomposition - Percentage contribution to standard error of TOT

\begin{tabular}{lcrcc}
\hline Period & $\begin{array}{c}\text { Forecasted } \\
\text { standard error }\end{array}$ & TOT & $\begin{array}{c}\text { Economic } \\
\text { growth }\end{array}$ & $\begin{array}{c}\text { Current account } \\
\text { balance (\% GDP) }\end{array}$ \\
\hline 1 & 0.08 & 100.0 & 0.000 & 0.00 \\
2 & 0.09 & 94.4 & 0.005 & 5.54 \\
3 & 0.10 & 89.0 & 0.004 & 10.9 \\
4 & 0.11 & 85.2 & 0.020 & 14.7 \\
5 & 0.11 & 82.6 & 0.064 & 17.2 \\
6 & 0.11 & 80.9 & 0.138 & 18.9 \\
7 & 0.11 & 79.6 & 0.239 & 20.1 \\
8 & 0.12 & 78.6 & 0.359 & 20.9 \\
9 & 0.12 & 77.9 & 0.493 & 21.5 \\
10 & 0.12 & 77.3 & 0.635 & 22.0 \\
\hline
\end{tabular}

Source: Authors' calculations.

Table 7 shows that most of the forecast error variance in economic growth is accounted for by the variable itself. The role of the current account balance is more prominent in explaining the standard error of economic growth, contributing almost 46.34 percent of the variation in economic growth. However, over longer time horizons in Pakistan, innovations in TOT have a minor effect on economic growth. We observe that merely 0.77 percent of the forecast variance of economic growth is explained by innovations in TOT. The variance decomposition analysis reveals that the standard error variation of economic growth is more affected by innovations in the current account balance rather than innovations in TOT. 
Table 7: Forecast error variance decomposition - Percentage contribution to standard error of economic growth

\begin{tabular}{lcccc}
\hline Period & $\begin{array}{c}\text { Forecasted } \\
\text { standard error }\end{array}$ & TOT & $\begin{array}{c}\text { Economic } \\
\text { growth }\end{array}$ & $\begin{array}{c}\text { Current account } \\
\text { balance (\% GDP) }\end{array}$ \\
\hline 1 & 0.01 & 1.06 & 98.9 & 0.00 \\
2 & 0.02 & 0.52 & 88.0 & 11.4 \\
3 & 0.02 & 0.33 & 77.8 & 21.8 \\
4 & 0.03 & 0.26 & 70.5 & 29.2 \\
5 & 0.03 & 0.28 & 65.2 & 34.4 \\
6 & 0.03 & 0.35 & 61.4 & 38.1 \\
7 & 0.04 & 0.45 & 58.5 & 41.0 \\
8 & 0.04 & 0.56 & 56.2 & 43.2 \\
9 & 0.04 & 0.67 & 54.3 & 44.9 \\
10 & 0.05 & 0.77 & 52.8 & 46.3 \\
\hline
\end{tabular}

Source: Authors' calculations.

Table 8 shows that a large portion of the forecast error variance in the current account is explained by the variable itself. However, innovations in TOT play a relatively large role in the forecasted error of the current account balance, contributing around 4.22 percent to the forecasted error of Pakistan's current account balance. Moreover, the economic growth shock does not dominate in explaining fluctuations in the current account balance since it contributes only around 1.15 percent of the variations in the current account balance. Thus, we can establish that variations in Pakistan's current account balance can be attributed largely to innovations in TOT. 
Table 8: Forecast error variance decomposition - Percentage contribution to standard error of current account balance

\begin{tabular}{lcccc}
\hline Period & $\begin{array}{c}\text { Forecasted } \\
\text { standard error }\end{array}$ & TOT & $\begin{array}{c}\text { Economic } \\
\text { growth }\end{array}$ & $\begin{array}{c}\text { Current account } \\
\text { balance (\% GDP) }\end{array}$ \\
\hline 1 & 2.46 & 0.07 & 1.12 & 98.8 \\
2 & 2.78 & 1.00 & 1.00 & 97.9 \\
3 & 2.89 & 2.15 & 0.93 & 96.9 \\
4 & 2.95 & 2.99 & 0.90 & 96.1 \\
5 & 2.98 & 3.52 & 0.90 & 95.5 \\
6 & 3.00 & 3.83 & 0.93 & 95.2 \\
7 & 3.02 & 4.02 & 0.97 & 95.0 \\
8 & 3.03 & 4.12 & 1.02 & 94.8 \\
9 & 3.03 & 4.19 & 1.08 & 94.7 \\
10 & 3.04 & 4.22 & 1.15 & 94.6 \\
\hline
\end{tabular}

Source: Authors' calculations.

\section{Conclusion}

This paper has empirically examined the existence of the HLM effect in Pakistan's case. The macroeconomic variables included in the analysis are real GDP, net barter TOT, and the current account balance as a percentage of GDP, for annual data over the period 1980-2009.

According to the results of our impulse response analysis, a Cholesky one-standard deviation shock to TOT creates a negative adjustment to real output in Pakistan. This adjustment confirms that an appreciation in domestic currency leads to Dutch Disease (Hernández, 2011). The major exports of developing countries, however, are mainly primary commodities with a low price elasticity of demand-an improvement in TOT does not guarantee that their economies will grow. Changes in TOT may, however, affect developing economies manifold (Broda, 2004).

The World Bank's (2006) analysis finds that Pakistan, like other developing countries, relies heavily on primary goods for its exports, and facings a low price elasticity of demand-hence, it cannot affect world market prices. Such countries' major imports include machinery, petroleum products, and capital-intensive goods with which to run their domestic industry. Therefore, Pakistan's current account balance remains vulnerable to changes in the world economy. The sharp increase in crude 
oil prices has fueled the import bill significantly. The deterioration in the current account deficit has emanated mainly from the rapidly widening trade deficit in Pakistan.

Developing economies tend to suffer even in the presence of favorable TOT. Pinto (1987), Murphy (1983), Gelb (1988), Robinson and Ragnar (2005) and others emphasize that the windfall gains from an improvement in TOT can be squandered on white elephant projects in developing countries. Another striking aspect, i.e., the voracity effect, cannot be overlooked since it dissipates the gains of improved TOT. The results of our impulse response analysis illustrate that Cholesky onestandard deviation innovations in TOT lead to a negative response by the current account balance. However, favorable TOT affect Pakistan adversely because its demand for import content increases for consumption and investment, placing a burden on the current account balance. The results therefore show the nonexistence of the HLM effect in Pakistan.

Keeping in view the results of this study, we suggest that Pakistan focus on the composition of its exports. There is a need to search for new markets for exports and the trading sector should develop to the extent that it is capable of exporting capital-intensive goods rather than importing them. With reference to the results of the impulse response function, with the windfall of TOT, economic growth can be increased by utilizing resources efficiently. In order to attain maximum benefits from TOT gains, the government should ensure investment in high-return projects, along with transparency in the public and private sectors in order to steer clear of the voracity effect. The results of the variance decomposition showed that economic growth is affected mainly by the current account balance. Accordingly, Pakistan should pursue policy aimed at increased exports and reducing imports. 


\section{References}

Agénor, P.-R., \& Aizenman, J. (2004). Saving and the terms of trade under borrowing constraints. Journal of International Economics, 63(2), 321-340.

Amisano, G., \& Giannini, C. (1997). Topics in structural VAR econometrics (2nd ed.). Heidelberg, Germany: Springer-Verlag.

Bhargava, A. (1984). On the theory of testing for unit roots in observed time series. Unpublished manuscript, International Centre for Economics and Related Disciplines, London School of Economics, UK.

Bouakez, H., \& Kano, T. (2008). Terms of trade and current account fluctuations: The Harberger-Laursen-Metzler effect revisited. Journal of Macroeconomics, 30(1), 260-281.

Broda, C. (2004). Terms of trade and exchange rate regimes in developing countries. Journal of International Economics, 63(1), 31-58.

Cashin, P., \& McDermott, C. J. (2002). The long-run behavior of commodity prices: Small trends and big variability. International Monetary Fund Staff Papers, 49(2), 175-199.

Chinn, M. D., \& Prasad, E. S. (2003). Medium-term determinants of current accounts in industrial and developing countries: An empirical exploration. Journal of International Economics, 59, 47-76.

Debelle, G., \& Faruquee, H. (1996). What determines the current account? A cross-sectional and panel approach (Working Paper No. 96/58). Washington, DC: International Monetary Fund.

Edwards, S. (1989). Temporary terms-of-trade disturbances, the real exchange rate and the current account. Economica, 56(223), 343-357.

Fry, M. J. (1986). Terms-of-trade dynamics in Asia: An analysis of national saving and domestic investment responses to terms-of-trade changes in 14 Asian LDCs. Journal of International Money and Finance, 5(1), 57-73.

Gelb, A. (1988). Oil windfalls: Blessing or curse? New York, NY: Oxford University Press. 
Goodger, T. H. (2001). Terms of trade and present value tests of intertemporal current account models: Evidence from the United Kingdom and Canada. Unpublished manuscript, University of North Carolina, Chapel Hill, NC.

Harberger, A. C. (1950). Currency depreciation, income, and the balance of trade. Journal of Political Economy, 58(1), 47-60.

Hassan, A. F. M. K. (2006). Determinants of current account deficit in developing countries: The case of Bangladesh. Studies in Business and Economics, 12(1), 5-24.

Hernández, G. (2011). Terms of trade and output fluctuations in Colombia (Working Paper No. 2011-04). Amherst, MA: University of Massachusetts Amherst, Department of Economics.

Khan, A. H., Hasan, L., \& Malik, A. (1992). Dependency ratio, foreign capital inflows and the rate of savings in Pakistan. Pakistan Development Review, 31(4, Pt. II), 843-856.

Khan, M. S., \& Knight, M. D. (1983). Determinants of the current account balances of non-oil developing countries in the 1970s: An empirical analysis. International Monetary Fund Staff Papers, 30(4), 819-842.

Laursen, S., \& Metzler, L. A. (1950). Flexible exchange rates and the theory of employment. Review of Economics and Statistics, 32(4), 281-299.

Mendoza, E. (1995). The terms of trade, the real exchange rate, and economic fluctuations. International Economic Review, 36(1), 101-137.

Misztal, P. (2010). The Harberger-Laursen-Metzler effect: Theory and practice in Poland. Romanian Economic Journal, 13(38), 129-146.

Murphy, K. J. (1983). Macroproject development in the Third World: An analysis of transnational partnerships. Boulder, CO: Westview Press.

Obstfeld, M. (1982). Aggregate spending and the terms of trade: Is there a Laursen-Metzler effect? Quarterly Journal of Economics, 97(2), 251270. 
Obstfeld, M., \& Rogoff, K. (1994). The intertemporal approach to the current account (Working Paper No. 4893). Cambridge, MA: National Bureau of Economic Research.

Onder, G., \& Anil, N. (2006). A VAR analysis of the current account. Master's thesis, Department of Economics, North Carolina State University, Raleigh, NC.

Ostry, J. D., \& Reinhart, C. M. (1992). Private saving and terms of trade shocks: Evidence from developing countries. International Monetary Fund Staff Papers, 39(3), 495-517.

Otto, G. (2003). Terms of trade shocks and the trade balance of trade: There is a Harberger-Laursen-Metzler Effect? Journal of International Money and Finance, 22, 155-184.

Pearce, I. F. (1955). A note on Mr. Spraos' paper. Economica, 22, 147-151.

Persson, T., \& Svensson, L. E. O. (1985). Current account dynamics and the terms of trade: Harberger-Laursen-Metzler two generations later. Journal of Political Economy, 93(1), 43-65.

Pinto, B. (1987). Nigeria during and after the oil boom: A policy comparison with Indonesia. World Bank Economic Review, 1(3), $419-445$.

Razin, A. (1993). The dynamic-optimizing approach to the current account: Theory and evidence (Working Paper No. 4334). Cambridge, MA: National Bureau of Economic Research.

Robinson, J. A., \& Ragnar, T. (2005). White elephants. Journal of Public Economics, 89, 197-210.

Sachs, J. D. (1981). The current account and macroeconomic adjustment in the 1970s. Brookings Papers on Economic Activity, 1, 201-268.

Sen, P., \& Turnovsky, S. J. (1989). Deterioration of the terms of trade and capital accumulation: A re-examination of the Laursen-Metzler effect. Journal of International Economics, 26, 227-250.

Servén, L. (1995). Capital goods imports, the real exchange rate and the current account. Journal of International Economics, 39, 79-101. 
Sims, C. A. (1980). Macroeconomics and reality. Econometrica, 48(1), 1-48.

Sobrino, C. R. (2008). Current account, productivity, and terms of trade shocks in Norway (Working paper). Morgantown, WV: West Virginia University, College of Business and Economics.

Stock, J. H., \& Watson, M. W. (2001). Vector autoregressions. Journal of Economic Perspectives, 15(4), 101-115.

Svensson, L. E. O., \& Razin, A. (1983). The terms of trade and the current account: The Harberger-Laursen-Metzler effect. Journal of Political Economy, 91(1), 97-125.

Tornell, A., \& Lane, P. (1994). Are windfalls a curse? A nonrepresentative agent, model of current account and fiscal policy (Working Paper No. 4839). Cambridge, MA: National Bureau of Economic Research.

World Bank. (2006). Pakistan: Growth and export competitiveness (Report No. 35499-PK). Washington, DC: Author: Poverty Reduction and Economic Management Sector Unit, South Asia. 


\section{Appendix A}

The steps involved in the construction of the model are given as follows.

$$
X_{t}=A(L) X_{t-1}+U_{t}
$$

where $X_{t}$ is a $3 \times 1$ vector of endogenous variables, i.e., $X_{t}{ }^{\prime} \equiv\left[\right.$ tot $\left._{t}, y_{t}, c a_{t}\right]$

$A(L)$ is a $3 \times 3$ matrix of lag polynomials and $U_{t}$ is a $3 \times 1$ vector reducedform innovation, i.e., $U_{t} \equiv\left[u_{t}^{t o t}, u_{t}^{y}, u_{t}^{c a}\right]$. These residuals are independently and identically distributed with a variance-covariance matrix, where $E\left(U_{t}\right)=0 ; E\left(U_{t} U_{t}^{\prime}\right)=\sum u_{t}$

Amisano and Giannini (1997) suggest the following relationship between reduced-form and form structural shocks in the form of an $A B$ model:

$$
A U_{t}=B V_{t}
$$

$V_{t}$ represents structural shocks and $A$ and $B$ are $3 \times 3$ matrices that reflect the instantaneous relationship between variables and the linear relationship between shocks and reduced-form innovation, respectively. Consequently, the recursive form of VAR can be obtained from reduced form by pre-multiplying equation (1) with $A$ as

$$
A X_{t}=A A(L) X_{t-1}+A U_{t}
$$

Replacing $A U_{t}$ with $B V_{t}$, we get

$$
\begin{gathered}
A X_{t}=A A(L) X_{t-1}+B V_{t} \\
{\left[\begin{array}{ccc}
1 & -\alpha_{12} & -\alpha_{13} \\
-\alpha_{21} & 1 & -\alpha_{23} \\
-\alpha_{31} & -\alpha_{32} & 1
\end{array}\right]\left[\begin{array}{c}
t o t_{t} \\
y_{y} \\
c a_{t}
\end{array}\right]=\left[\begin{array}{lll}
\beta_{11} & \beta_{12} & \beta_{13} \\
\beta_{21} & \beta_{22} & \beta_{23} \\
\beta_{31} & \beta_{32} & \beta_{33}
\end{array}\right]\left[\begin{array}{c}
t o t_{t-1} \\
y_{t-1} \\
c a_{t-1}
\end{array}\right]+\left[\begin{array}{ccc}
1 & \gamma_{12} & \gamma_{13} \\
\gamma_{21} & 1 & \gamma_{23} \\
\gamma_{31} & \gamma_{32} & 1
\end{array}\right]\left[\begin{array}{c}
u_{t}^{\text {tot }} \\
u_{t}^{y} \\
u_{t}^{c a}
\end{array}\right]}
\end{gathered}
$$

Solving equation (4) for $X_{t}$ we get

$$
X_{t}=A^{-1} A(L) X_{t-1}+A^{-1} B V_{t}
$$




$$
\begin{aligned}
{\left[\begin{array}{c}
\text { tot }_{t} \\
y_{y} \\
c a_{t}
\end{array}\right]=} & {\left[\begin{array}{ccc}
1 & -\alpha_{12} & -\alpha_{13} \\
-\alpha_{21} & 1 & -\alpha_{23} \\
-\alpha_{31} & -\alpha_{32} & 1
\end{array}\right]^{-1}\left[\begin{array}{ccc}
\beta_{11} & \beta_{12} & \beta_{13} \\
\beta_{21} & \beta_{22} & \beta_{23} \\
\beta_{31} & \beta_{32} & \beta_{33}
\end{array}\right]\left[\begin{array}{c}
t^{t} t_{t-1} \\
y_{t-1} \\
c a_{t-1}
\end{array}\right]+} \\
& {\left[\begin{array}{ccc}
1 & -\alpha_{12} & -\alpha_{13} \\
-\alpha_{21} & 1 & -\alpha_{23} \\
-\alpha_{31} & -\alpha_{32} & 1
\end{array}\right]^{-1}\left[\begin{array}{ccc}
1 & \gamma_{12} & \gamma_{13} \\
\gamma_{21} & 1 & \gamma_{23} \\
\gamma_{31} & \gamma_{32} & 1
\end{array}\right]\left[\begin{array}{c}
u_{t}^{\text {tot }} \\
u_{t}^{y} \\
u_{t}^{c a}
\end{array}\right] }
\end{aligned}
$$

The summarized form of equation (5) can be written as:

$$
X_{t}=A(L) X_{t-1}+\varepsilon_{t}
$$

Whereas

$$
\begin{aligned}
& C(L)=A^{-1} A(L) \\
& \varepsilon_{t}=A^{-1} B V_{t} \\
& {\left[\begin{array}{c}
\varepsilon_{t}^{t o t} \\
\varepsilon_{t}^{y} \\
\varepsilon_{t}^{c a}
\end{array}\right]=\left[\begin{array}{ccc}
1 & -\alpha_{12} & -\alpha_{13} \\
-\alpha_{21} & 1 & -\alpha_{23} \\
-\alpha_{31} & -\alpha_{32} & 1
\end{array}\right]^{-1}\left[\begin{array}{ccc}
1 & \gamma_{12} & \gamma_{13} \\
\gamma_{21} & 1 & \gamma_{23} \\
\gamma_{31} & \gamma_{32} & 1
\end{array}\right]\left[\begin{array}{c}
\mu_{t}^{t o t} \\
\mu_{t}^{y} \\
\mu_{t}^{c a}
\end{array}\right]}
\end{aligned}
$$

Equation (6) is the autoregressive representation of the model in which each variable is expressed as a function of the past values of itself and of the other variables in the system. It also shows that reduced-form innovations are a linear combination of recursive innovations. 


\section{Appendix B}

\section{VAR RESULTS}

Sample (adjusted): 19812009

Included observations: 29 after adjustments

Model: $\mathrm{Ae}=\mathrm{Bu}$ where E[uu']=I

Restriction type: short-run pattern matrix

$\mathrm{A}=$

$\mathrm{C}(1)$

$0 \quad 0$

$\mathrm{C}(2)$

C(4) 0

$\mathrm{C}(3)$

$\mathrm{C}(5) \quad \mathrm{C}(6)$

$\mathrm{B}=$

1

0

0

$0 \quad 0$

$1 \quad 0$

$\begin{array}{lll}0 & 0 & 1\end{array}$

\begin{tabular}{lllll}
\hline & Coefficient & Std. error & z-statistic & Prob. \\
\hline $\mathrm{C}(1)$ & 12.12659 & 1.592299 & 7.615773 & 0.0000 \\
$\mathrm{C}(2)$ & 1.260368 & 2.257923 & 0.558198 & 0.5767 \\
$\mathrm{C}(3)$ & 0.198400 & 2.264130 & 0.087628 & 0.9302 \\
$\mathrm{C}(4)$ & 66.95133 & 8.791140 & 7.615773 & 0.0000 \\
$\mathrm{C}(5)$ & -7.139441 & 12.46784 & -0.572628 & 0.5669 \\
$\mathrm{C}(6)$ & -0.408136 & 0.053591 & -7.615773 & 0.0000 \\
\hline
\end{tabular}

Log likelihood 44.84547

Estimated A matrix

\begin{tabular}{lll}
\hline 12.12659 & 0.000000 & 0.000000 \\
1.260368 & 66.95133 & 0.000000 \\
-0.198400 & 7.139441 & 0.408136
\end{tabular}

\begin{tabular}{lll}
\hline \multicolumn{3}{l}{ Estimated B matrix } \\
\hline 1.000000 & 0.000000 & 0.000000 \\
0.000000 & 1.000000 & 0.000000 \\
0.000000 & 0.000000 & 1.000000 \\
\hline
\end{tabular}

